\title{
Spontaneous resolution of idiopathic lumbar subdural hygroma on CT myelography and lumbar spine MRI
}

\author{
Chong K Yi, Timothy J Biega, Ricardo M Burgos
}

Department of Radiology, Tripler Army Medical Center, Honolulu, Hawaii, USA

\section{Correspondence to} Dr Chong K Yi, chong.k.yi1.mil@mail.mil

Accepted 31 July 2014
CrossMark

To cite: Yi CK, Biega TJ, Burgos RM. BMJ Case Rep Published online: [please include Day Month Year] doi:10.1136/bcr-2014206223

\section{DESCRIPTION}

A 23-year-old man with a history of limited right ankle dorsiflexion presented to the MRI suite for a routine lumbar spine MRI. The patient denied history of prior spinal trauma or systemic symptoms. Aside from mild right ankle pain, physical and neurological examinations were unremarkable.

Lumbar spine MRI revealed subdural fluid collections at T12-S1 levels (figure 1A, B). Follow-up enhanced brain MRI (not shown) and
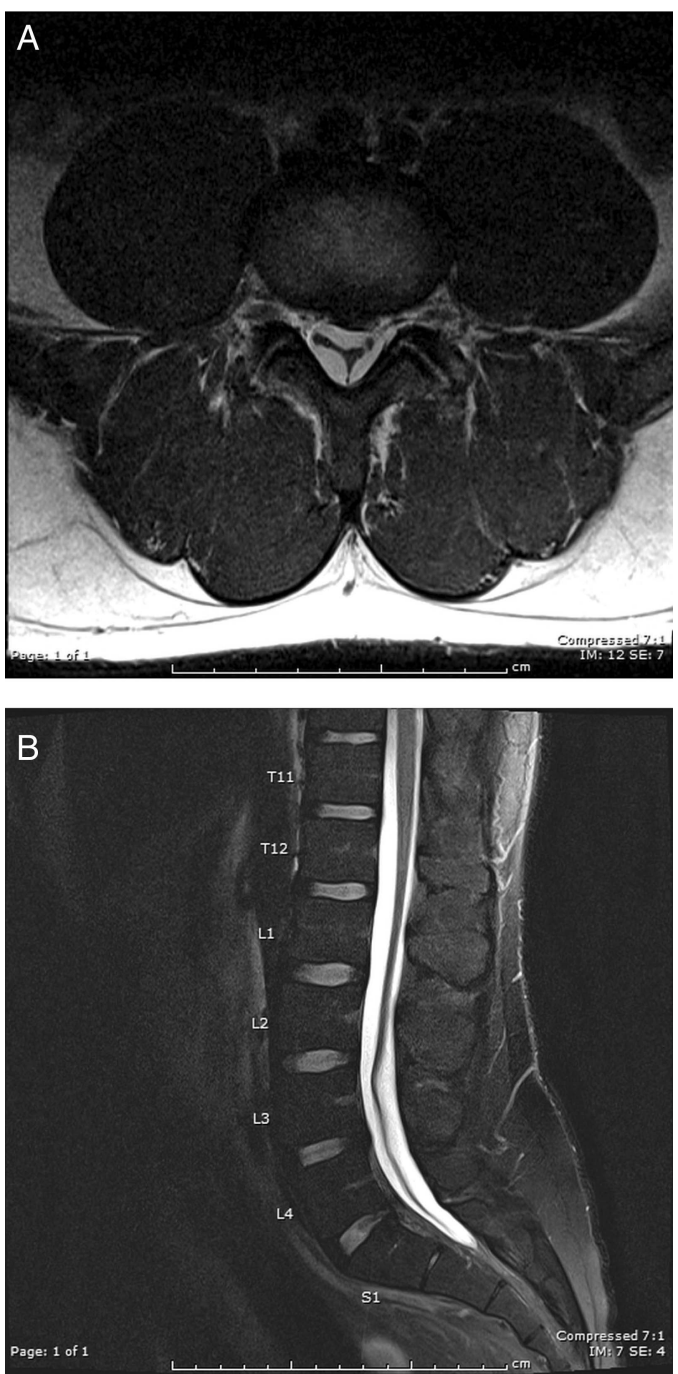

Figure 1 Lumbar spine MRI. Axial proton density image at L3-L4 (A) and mid-sagittal fat suppressed T2-weighted image (B) of the lumbar spine demonstrate hyperintense T2 subdural fluid collections at T12-S1 without displacement of the hypointense dura. There is a small left L3-L4 paracentral disc protrusion. Twenty-three presacral vertebral bodies were incidentally noted. cervicothoracic spine MRI (not shown) in the same week were both unremarkable, with no evidence of intracranial hypotension or extra-arachnoid fluid collections. Two weeks later, CT myelogram (figure 2A, $\mathrm{B}$ ) and repeat lumbar spine MRI (figure 3A, B; immediately following the CT myelogram) demonstrated complete resolution of lumbar subdural hygroma.

Spinal subdural hygroma has previously been associated with intracranial hypotension or as a
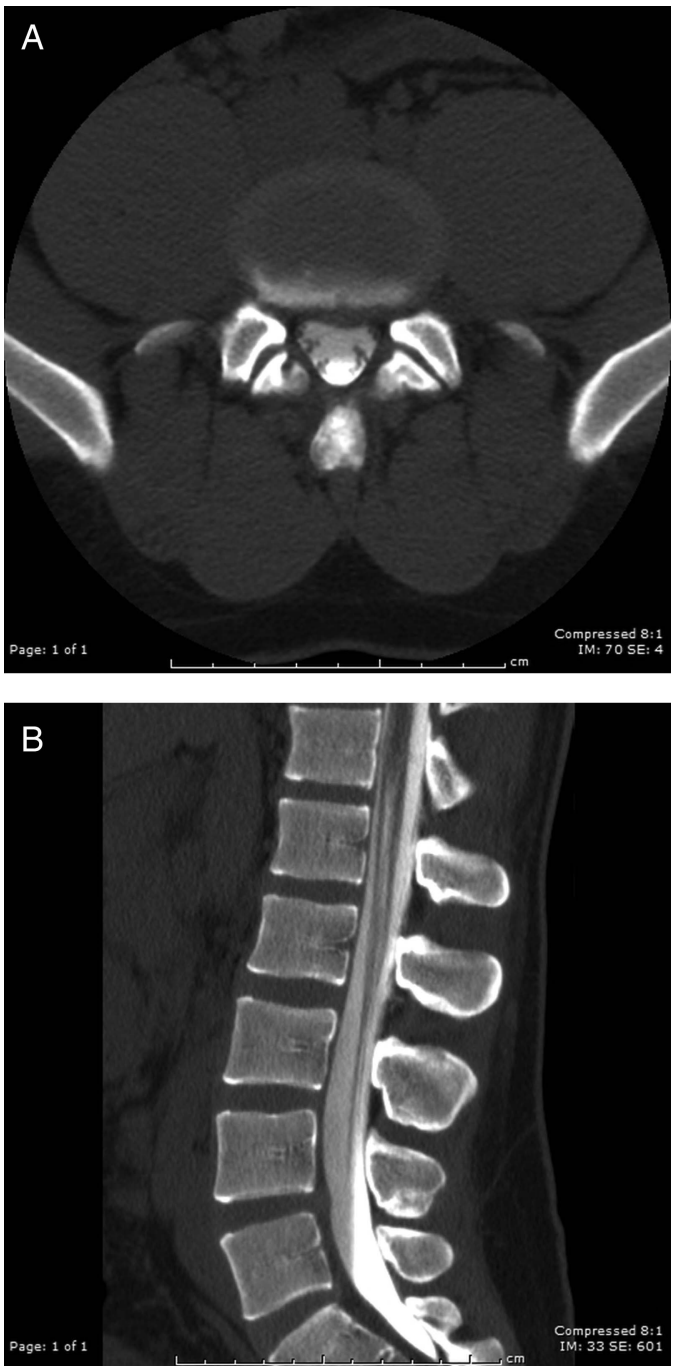

Figure 2 CT myelogram. Axial image at L3-L4 (A) and mid-sagittal image $(B)$ of the lumbar spine with intrathecal contrast reveal no evidence of extra-axial fluid collection, cerebrospinal fluid leak, or clumping of nerve roots. 

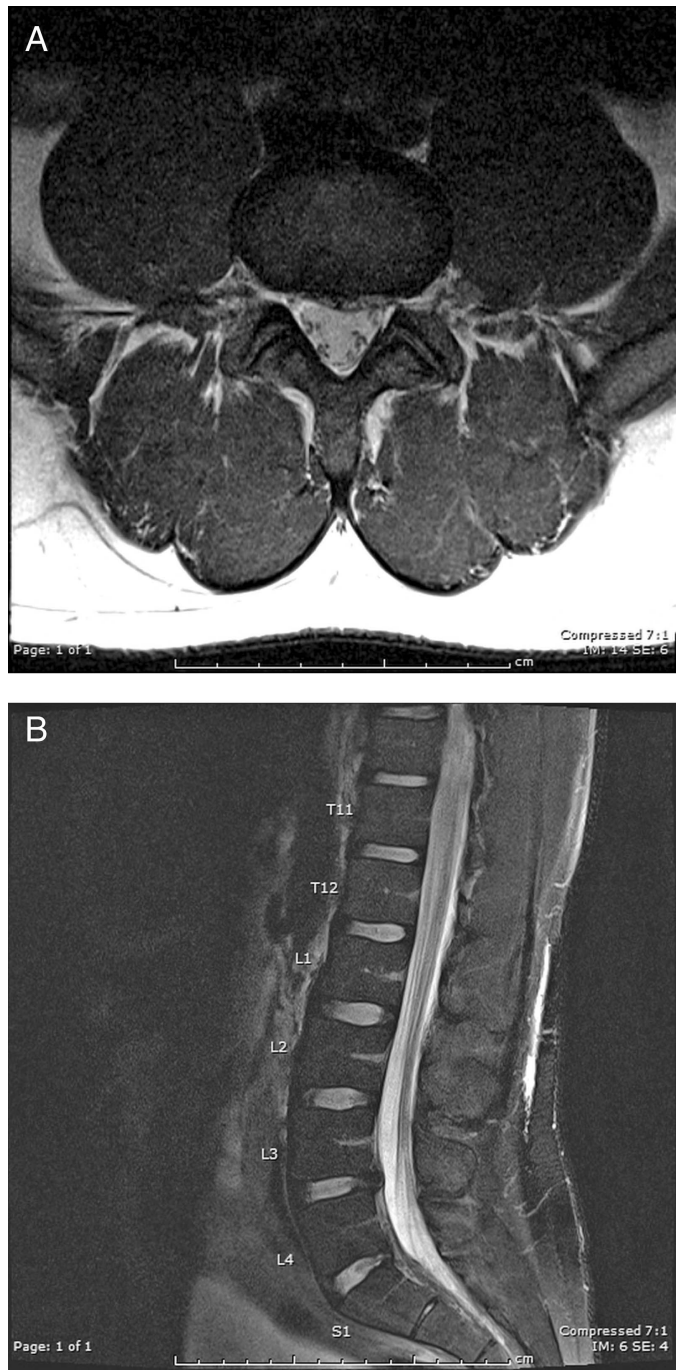

Figure 3 Lumbar spine MRI. Axial proton density image at L3-L4 (A) and mid-sagittal fat suppressed T2-weighted image (B) of the lumbar spine immediately following the CT myelogram confirm complete resolution of lumbar subdural hygroma.

complication of spinal procedures. ${ }^{1}{ }^{2}$ Spontaneous resolution of idiopathic lumbar subdural hygroma has not been reported in the literature, to the best of our knowledge. On imaging, spinal subdural fluid collection typically demonstrates outer convex and inner concave margins with fluid between the spinal cord and the dura. In contrast, epidural fluid collection typically appears biconvex and displaces the dura away from the bony canal. CT myelogram may reveal the location and extension of cerebrospinal fluid (CSF) leaks. ${ }^{1}{ }^{2}$ CSF leaks manifest as spinal extra-arachnoid fluid collections, which are commonly caused by lumbar puncture, trauma, spinal surgery, and intracranial hypotension. Although less common, there is evidence suggesting that spontaneous CSF leaks may be associated with connective tissue disorders, such as Marfan syndrome. ${ }^{3}$

\section{Learning points}

- Spontaneous resolution of idiopathic lumbar subdural hygroma has not been reported in the literature, to the best our knowledge.

- Spinal subdural hygroma is best evaluated by MRI, and in the appropriate clinical setting, CT myelography. CT myelography may be used to reveal the location and extension of cerebrospinal fluid (CSF) leak.

- CSF leaks manifest as spinal extra-arachnoid fluid collections and are often caused by lumbar puncture, trauma, spinal surgery, intracranial hypotension, and less commonly, connective tissue disorders.

Competing interests None.

Patient consent Obtained.

Provenance and peer review Not commissioned; externally peer reviewed.

\section{REFERENCES}

1 Schievink WI. Spontaneous spinal cerebrospinal fluid leaks. Cephalalgia 2008;28:1345-56

2 Luetmer PH, Schwartz KM, Eckel LJ, et al. When should I do dynamic CT myelography? Predicting fast spinal CSF leaks in patients with spontaneous intracranial hypotension. AJNR Am J Neuroradiol 2012;33:690-4.

3 Mokri B, Maher CO, Sencakova D. Spontaneous CSF leaks: underlying disorder of connective tissue. Neurology 2002;58:814-16.

Copyright 2014 BMJ Publishing Group. All rights reserved. For permission to reuse any of this content visit

http://group.bmj.com/group/rights-licensing/permissions.

BMJ Case Report Fellows may re-use this article for personal use and teaching without any further permission.

Become a Fellow of BMJ Case Reports today and you can:

- Submit as many cases as you like

- Enjoy fast sympathetic peer review and rapid publication of accepted articles

- Access all the published articles

- Re-use any of the published material for personal use and teaching without further permission

For information on Institutional Fellowships contact consortiasales@bmjgroup.com

Visit casereports.bmj.com for more articles like this and to become a Fellow 